\title{
TOURISM DEVELOPMENT: AN ECONOMIC RECOVERY OPPORTUNITY FOR CÂMPULUNG MUSCEL DEPRESSION
}

\author{
Aurel Gheorghilaş*, Cosmin Ciprian Caraba, Mihaela Ploaie Teodorescu \\ University of Bucharest, Faculty of Geography, Bucharest, Romania
}

\begin{abstract}
Developing tourism in an area represents the continuous process of planning and building tourist facilities, refurbishing and modernizing the existing ones, resizing them according to the types and sizes of tourist fluxes, shaping demand and offer, rendering a sustainable tourist activity. Perspective studies on the evolution of the phenomenon are necessary to design the tourist activity, following the insertion of the future area parameters into the decision models allowing them to be monitored and changed during the modelling process. Given the geographic really of space, the present study focuses on highlighting several indicators concerning tourism development in an area severely affected by economic cut backs, suggesting and also trying to monitor the social and economic effects tourism development could have upon. Besides determining the function of the territory, authors have conducted a diagnostic analysis which underlines the favourable factors of tourism, indicating, at the same time, the necessary measures to insure the best development. Thus, given the conditions of massive cut backs in the major economic sectors, the local development of tourism is of a crucial importance. As a key element of the sustainable development, tourism could provide new business and work places in the same time; it could determine the increase of incomes for the rural area habitants through the capitalization of local resources.
\end{abstract}

Key words: Tourism potential, Accommodation, Tourism function, Tourism development, Economic recovery.

Article Info: Manuscript Received: February 14, 2012; Revised: July 16, 2012 Accepted: September 10, 2012; Online: November $30,2012$.

\section{Introduction and research methods}

Tourism planning as process, aims to improve exploitation of the tourism potential. This action is measured by several indicators of correlation between tourism flows, accommodation facilities and tourism resources. The tourism function of a certain space is a key indicator that shows the degree of development of tourism, namely the degree of development / exploitation of tourism resources in a given area (Stănciulescu et al., 1998). Its size can be expressed in terms of tourist accommodation capacity equipment and permanent population of the area. After a comprehensive literature review we can see that several different opinions have been issued on the topic of tourism planning. Thus, Prikvil (1967) states that such action is "a planned development effort

\footnotetext{
* Corresponding author:

Address: University of Bucharest, Faculty of Geography, 1, Nicolae Bălcescu Avenue, 010041, Bucharest, Romania.

Telephone: +4.0724 .987 .487$

Email: aghgeo@yahoo.com
}

doi:10.5719/hgeo.2012.62.63 applied to different sectors of the national economy to achieve an optimal solution for the coordinated development of an area as a whole". Prikvil (1967) emphasize that, from the point of view of tourism marketing, the development of an area as a tourism product has a significant importance, since the use of other marketing tools (pricing, distribution, and promotion) is subject to its scientific validity (Berbecaru, Botez, 1977). Integrated in a systematic policy planning, tourism planning follows specific aims, ensures a constant development of certain regions and stimulates a balanced growth at higher rates than the general economic whole (Cristureanu et al., 1982).

In order to optimize the developing system's functionality, it is necessary to know and describe behaviour and interaction of its components, since any change that occurs can shift the balance of the system. Therefore, each potential changes are analysed according to form, magnitude, intensity and correlations between them and to the degree in which it may or may not be controlled as follows (Rău, 1981): organization of tourist areas and taxonomic subdivisions in a systemic vision, in which 
the components of the tourism system are integrated in the network of systems or subsystems of localities; ensuring a permanent cooperation between system components, tourism (resorts, usually) and other localities in the same area or between different tourist areas, in order to develop common economic or socio-cultural objectives, engineering services, infrastructure, water and electricity supply etc.., to ensure a high economic and social efficiency of investment; ensuring that the terms of the effective capitalization of high tourism potential areas by avoiding the location and development of elements that may lead to degradation of the environment and disruption of tourism in those areas or near them; ensuring fair tourism facilities development proportions, in relation to the tourism resources found in the area, so as to avoid degradation due to excessive development of surface occupied by buildings of perimeters with various tourist resources and valuable natural environment; the preservation, conservation and improvement of the environmental quality by developing adequate facilities and by their spatial distribution and by creating, where appropriate, natural reserves which, can be visited by organized groups of tourists.

Based on these considerations, we emphasize that tourism development prospects of human settlements across the Câmpulung depression are closely related to the development of the infrastructure and the quality of public services. Currently, to achieve a high level of infrastructure facilities and a real improvement in social and economic life in rural areas, the rural development programs and strategies and financial assistance in the field of agro-tourism and related policies are of great importance. The capitalization of tourism resources and the general tourism development must be organically linked with the general, complex systematization of the territory in order to ensure a harmonious development of all sectors and a combination of economic and social efficiency criteria. With free movement of capital, exploitation possibilities of the tourism resources of the network of settlements in Câmpulung Depression, and their inclusion in national and international circuits are wide, therefore it is required to make a detailed analysis of the spatial development with regards to the accommodation structures and also to determine the optimal tourism function which ensures a sustainable development of the tourism sector.

Methods. The study uses statistical data gathered by the National Institute of Statistics regarding accommodation facilities (number, type, number of beds, accommodation capacity in operation), tourism flows (arrivals and overnight stays) and population for each commune located in the Câmpulung Muscel Depression. Each indicator was analyzed for the period 1990 (or 2000 in some cases) -2008 highlighting the evolution patterns across the depression.

In order to determine the tourism function of the area and see if the region can be considered a tourism space we calculated two indicators. First we divided the accommodation capacity by the population of each commune in the Câmpulung Muscel Depression (beds/10oo inhabitants).

$$
I_{1}=\frac{\text { accomdation capacity }}{\text { Population }}(\text { Beds } / 1000 \text { inhabitants })
$$

The second indicator was obtained by reporting the accommodation capacity to the surface occupied by each commune (accommodation places/sq.km).

$$
I_{2}=\frac{\text { Accomdation capacity }}{\text { Surface Area }}(\text { Beds } / \text { Sq.Km. })
$$

\section{Strengths of the Câmpulung Muscel Depression}

The Câmpulung Depression itself presents, from a physical-geographic point of view, a typical subcarpathian depression, well individualized both tectonically and structurally. Around the city of Câmpulung the altitude is about $600 \mathrm{~m}$, the lowest value found in the depression, while on the structural or flat interfluves consisting of gravel, clay and marl, the altitude surpasses 70om. With an exceptional tourism potential, consisting of spectacular diverse landforms, and with a climate favorable to tourism throughout the whole year, endowed with rich flora and fauna and adorned with numerous historical and architectural monuments, the Câmpulung Depression has real possibilities to meet the needs of various segments of touristic demand. The contribution of tourism to the local resources exploitation is directly proportional to the presence of natural or man-made tourism resources, resembling in this respect, with the mining industry or agriculture. That is why there is a close relationship between the location of specific resources and tourism development, between the variety of resource and the different forms of tourism that can be practiced.

In the mountain landscape of the northern Câmpulung Depression the different landscapes blend with elements of hydrography, climate, vegetation, fauna, thus giving rise to special tourist resources that can generate specific forms of tourism. Targului River and its tributaries in this area (Cuca, Bătrâna, Râușor, etc.) have a high tourism potential, both by the fluvial landscape created, and also by the opportunities they offer to fishing amateurs. The 
hydro-electrical plant Râușor has further enriched the tourism potential of the area, increasing its attractiveness. Glacial lakes found in the mountainous landscape are by themselves important tourism attractions. The most representative is Lake Iezer located at $2130 \mathrm{~m}$ altitude at the foot of the mountain of the same name.

The mineral springs early discovered in Bughea de Sus were set off in 1922 by Dr. Gh Tănăsescu, the first physician of the Bughea baths, which established precise treatment rules. During communism, the bathrooms have been modernized by the construction of cabins, water capturing and heating installations, accommodation facilities etc. Despite setbacks registered by this form of tourism (spa tourism), after the December 1989 Revolution, due to the huge potential that it presents the Bughea area might become a starting point in reviving the local tourism in the future.

The reserves and natural monuments in the area are also particularly interesting. Of these, the geological and paleontological nummulitic limestone reserve near Albești is located in the west of the city Câmpulung. The first sector includes over 80 blocks of granite of different sizes that occupy an area of 250 $\mathrm{m}^{2}$. At a distance of $1.8 \mathrm{~km}$ from the first sector we can find the Albești limestone, a rare two-layered type of limestone, approx. $15 \mathrm{~m}$ thick (the top layer being a pure limestone layer). The two layers of limestone contain various fossils of lamellibranch, echinoderms, sharks etc. The fossil reserve at Suslănești (comuna Mioarele), located on the Argeșel valley, $6 \mathrm{~km}$ from the city of Câmpulung, occupies an area of approx. 1 ha on Hobaia hill. The foundation has preserved a rich fossil fauna of fish from 29 different species, of which 13 have been identified only in this area.

The manmade tourism resources cover a wide range of products that can be grouped into: 1) cultural tourism - historical resources (archaeological sites, religious monuments, memorials, museums, architectural monuments) - most of them concentrated in the city of Câmpulung, 2) sociodemographic tourism resources (ethno-cultural and ethno-folkloric sights) - many of the rural settlements are keepers of these priceless values of Romanian spirituality. Concentrating the main cultural sights of the region, the city of Câmpulung is a true hub of tourist flows. The city, the main beneficiary of the development in the region, meets the flow of tourists by providing a vast array of accommodation possibilities. Easy links to other regions, the obvious advantage in media and communication, transform the urban space into a promoter of cultural tourism.

In Câmpulung, tourism is conditioned by three major categories of premises: a) tourism fund consists of all the attraction factors - architectural monuments, groups of religious, historical and commemorative monuments, museum collections, b) the human factor - expresses a demand for a certain form of tourism, according to socio-cultural needs and individual financial possibilities, c) the technical and material base - which meets the wishes of both tourists and inhabitants - tourist facilities and services, accommodation, catering, sports, entertainment, recreation, commercial facilities and other public services are included here. The necessary elements required for tourism in an urban area are concentrated in the downtown area. The old part of the city concentrates several attractions / sights of priceless architectural, cultural, historical or religious value.

In the current socio-cultural context - in the Câmpulung Depression only a small number of forms of tourism are practiced, some of them (by example: rural tourism) being still in an early stage. It is no less true that, under the expanding range of services and their adaptation to international standards, local forms of tourism could be more diversified. Currently, the following major types can be distinguished:

- Transit tourism - related to the position of this area in relation to surrounding areas: the territory is crossed over by major axis connecting Transylvania to Muntenia (Brașov - Câmpulung - Pitesti, and from there to Bucharest, Craiova, Alexandria, etc.), or to the settlements located in the Subcarpathians (Câmpulung - Curtea de Argeș - Râmnicu Vâlcea Târgu Jiu). The transit flows are generally oriented towards the neighboring tourist areas: Rucăr, Bran, Brașov and Vâlcea;

- Cultural tourism - favoured by the existence of Câmpulung, a representative medieval centre for Wallachia (first capital of the country) with numerous cultural objectives. This major type of tourism is practiced mainly in an organized form. It's meaning is very complex, covering both an educational side (enriching knowledge) and a recreational side, felt on a spiritual level by discovering new truths and phenomenon. Unfortunately, the low quality of facilities in the urban area does not favour this type of tourism.

- Scientific tourism - this type of tourism is linked in this area to some unique attractions, of great scientific value, that gather important flows of specialists form different fields (geography, biology, paleontology, etc.). Among these attractions the most important ones are: the geological and paleontological reservation of nummulitic limestone from Albești, the fossil reservation from Suslănești and the Iezer Nature Reservation;

- Week-end tourism - is practiced especially by the inhabitants of Câmpulung, either individually or, more rarely, in organized groups (on special 
occasions) from May to September. This type of tourism is specific to families or groups of friends who prefer picnics in the vicinity of cottages or easily accessible meadows located near rivers, the most popular sectors being: Târgului River Valley upstream of the Râuşor dam, Bughiței Valley or Râusorul de Bratia;

- Rural tourism - although it is the newest form of tourism, it emerged in the subcarpathian villages, particularly those placed in contact with the mountains (Lerești, Voineşti, Nămăiești, Albești, Cândeşti etc.) which have important ethnographical resources represented by traditional architecture (houses with towers and fretted models of wooden pillars), traditional wear, specific folklore, traditional weaving with fabrics for personal use (towels, tablecloths) or strictly decorative fabrics (rugs, towels);

- Spa tourism - This type of tourism is only of local importance and has entered into obscurity due to a degradation of the specific treatment facilities (The Câmpulung Spa-Establishment - Kretulescu Baths - is in an advanced degree of degradation). There is hope for a major revival of this type of tourism due to the presence of a natural environment favourable for leisure and bicarbonate and sulfur mineral springs at Bughea de Sus, Câmpulung, Suslănești and Apa Sărată;

- Mountain tourism (mountain hiking) - linked to the presence to the north of the depression of the Iezer - Păpuşa Mountains, that attract by the presence of glacial gorges and small canyon sectors carved along the Târgului River, the Râuşor and Brătia. To encourage mountain hiking special markings have been put in place, with a total length of approx. $75 \mathrm{~km}$. These were made between 1936 and 1940 , then expanded in the years 1948-1950 by the competent bodies of the General Confederation of Tourism, and more recently, have passed in the administration of the Câmpulung Salvamont Department. During the same period, the first informative materials concerning the Iezer Mountains were published, designed as general geographic-touristic presentations or as detailed mapping work. However, the recreational infrastructure is very poor, the natural potential not being exploited to its full value. It is noted that there is no winter sports tourism in the area (although natural factors could allow this type of tourism) and no specific facilities (ski slopes, transport facilities etc.).

\section{Evolution of tourist accommodation structures}

The accommodation structures are the fundamental factors that support tourism, given their main characteristic, their economic efficiency. Through them, the economic component is added to the social component which leads to the appearance of the tourism phenomenon as a whole (Gheorghilaş, 2008). To assess the level of organization and development of the technical and material base for tourism in the Câmpulung Depression, in terms of reception facilities with accommodation and catering services, several indicators were taken into account: the existing tourist accommodation capacity, comfort level, types of accommodation units. Depending on the data available we have analysed both the depression as a whole and each administrative unit (commune / town) and settlement in particular.

In terms of the number of accommodation facilities in the Câmpulung Depression, there is a stagnation in their development until around the year 2000. After this year, a slight increase of the total number of units of accommodation units has been registered in the entire area. It should be noted however that at the administrative unit level, the evolution of the number of units is not uniform throughout the basin, some settlements have registered a slight increase, others stagnation, while others simply do not have accommodation facilities. In the entire area, a total number of 5 units were registered in 1990, 6 units in 2001 and 7 units in 2008, which means an average of one accommodation unit for each commune in 1990 and 1.4 accommodation units per commune in 2008.

However, this distribution is not uniform, for some communes in the area do not have any accommodation facilities. By comparing the existing situation at commune level in two different years, no major differences are noted, most settlements falling in the same category. Thus, according to official records, in the communes Albeștii de Muscel and Valea Mare Pravăț, no accommodation units are recorded, neither in 2001 nor in 2008. There are also communes where the number of accommodation units has varied between one and three, as in the case of Bughea de Jos (one unit throughout the period under review) and Lerești (two units recorded statistically in 1994, one unit until 1999, three units recorded in 2000 and 2002, two units in 2001 and between 2003-2006 and only one in 2007 and 2008). The most obvious increase in the number of accommodation units is recorded in the city of Câmpulung, which had two units in 1994, three units in 2004, four units in 2005 and five units after this year. 
If we were to analyse unofficial date, data collected through an internet search the situation is slightly different. Thus, in the city of Câmpulung, after 2008, 16 accommodation units were promoted on-line (many of them being classified between 2007 and 2008 and afterwards); in Albeștii de Muscel commune we have 4 accommodation units, in Lerești 9 accommodation units and in Valea Mare Pravăț we find 3 accommodation units.

In the Câmpulung Depression, the tourist accommodation capacity has seen a steady decline since 1990 when it counted over 700 beds, resulting in an average of approximately 141 beds per each administrative unit, until around 2003 when the total number of beds fell below 400, which means about only 79 beds per administrative unit; this happened although after 1999 there was a slight tendency to increase the total number of accommodation units; this year was followed by a short increase in the total accommodation available, but nowadays there is a constant decrease in the number of beds. A brief analysis of the situation in the two different years (Figure 1) shows that there were no major changes in the spatial distribution of the number of beds.

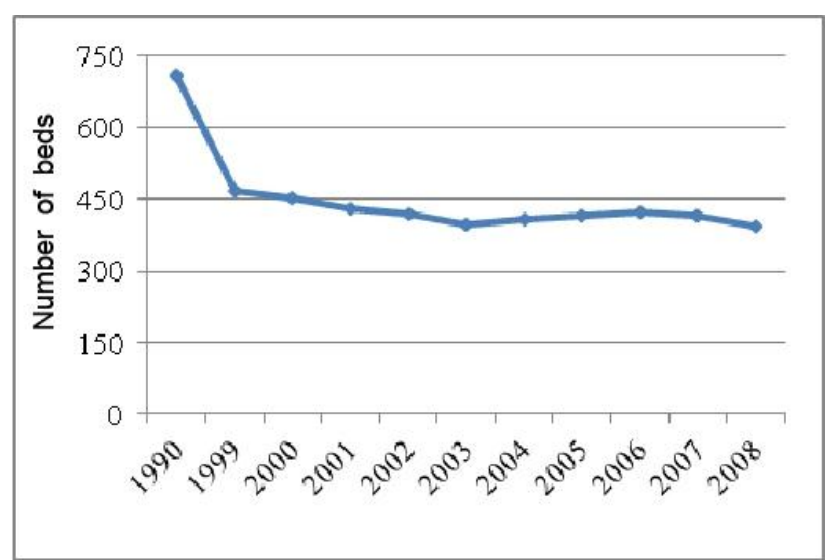

Figure 1. Evolution of the number of places in accommodation units

Thus, both in 2001 and 2008 Bughea de Sus commune had fewer than 100 beds and Lerești commune had between 100 and 200 beds in both years (142 places 2001, respectively 136 seats in 2008), while Albeștii de Muscel and Valea Mare Pravăț did not have accommodation facilities. An interesting situation is observed in the City of Câmpulung when analysing the evolution of the number of beds in comparison to the evolution of the number of accommodation units: although the number of units increased in 2008 compared to 2001 , the total number of beds decreased from 221 in 2001 to only 191 in 2008. According to unofficial data, obtained for the period after 2008, there were 1015 beds in the entire area, most of them being found in Câmpulung ( 486 beds) and Lerești ( 308 beds), well above the level of official data in 2008. A major difference appears between official and unofficial data when referring to the the situation in the villages of Albeștii de Muscel (including Bughea de Sus) and Valea Mare Pravăţ, totalling 143 and respectively 6o beds. In large part this is due to acknowledgment of several accommodation units in 2008 .

The tourist accommodation capacity in operation is the number of beds available to tourists in tourism accommodation units, taking into account the number of days these are open in the period taken into consideration. This indicator is expressed in place-days, and excludes the beds located in rooms or accommodation units temporarily closed in the offseason, for repairs or for other reasons. The existing data allowed an analysis of changes in accommodation capacity in operation since 2001 for the entire Câmpulung Muscel Depression (Figure 2). The analysis shows a fluctuating evolution for the entire area, so that at the beginning of the period taken into consideration, the accommodation capacity in operation experienced a decrease from approx. 140.000 place-days in 2001 to around 130.000 place-days in 2002, correlated with a slight decrease of the accommodation capacity. For the next period, although the existing accommodation capacity is maintained at around the same values, there is a rapid increase in accommodation capacity in operation. This positive trend is closely linked with an extension of the period of operation during the year. Thus a maximum is registered in 2006, when the accommodation capacity in operation in the entire Depression was over 152,00o place-days; this is followed by a period of decline.

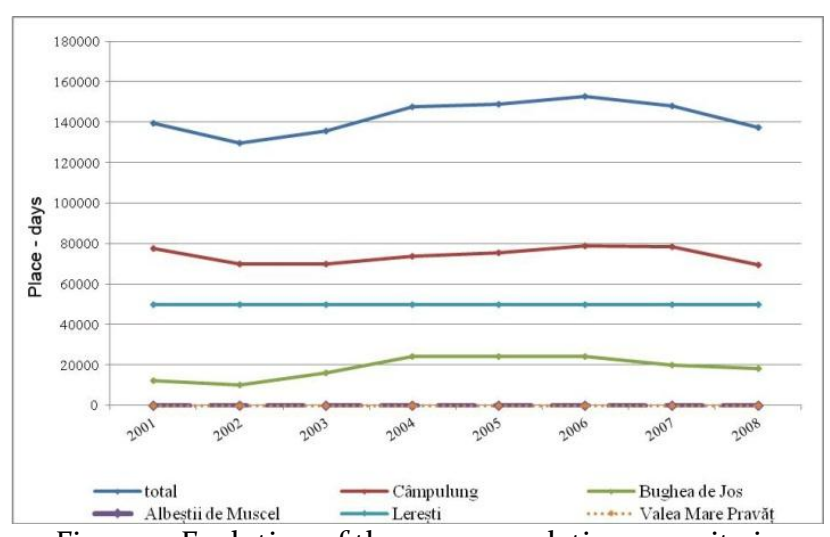

Figure 2. Evolution of the accommodation capacity in operation

In a first analysis of the accommodation capacity in operation, we observe that the general trend of evolution fits the following pattern: in 2001 (the first year of our analysis for which statistical data is available) and until 2002 the general trend of evolution for the accommodation capacity in use is decreasing due to a decrease of the tourist 
accommodation capacity. However, between 2002 2006, the accommodation capacity in operation has increased steadily from about 130.000 place-days in 2002 to 152,570 place-days in 2006 , after this period, enrolling again in the general decreasing trend, reaching just a little over 137.00o place-days in 2008.

A detailed analysis of each administrative unit reveals that throughout the period considered, the city of Câmpulung held most of the accommodation capacity in operation, more than half the total number of place-days available, the highest recorded value of this indicator being in $2007-78,840$ seats respectively. A different situation occurs in the village Lerești that, as illustrated above, throughout the period under review, the accommodation capacity in operation has been constant at about 50,000 placedays. For the communes Albeştii de Muscel and Valea Mare Pravăț, according to official data, we notice that this indicator is zero (in these two villages, officially, until the year 2008 , not one accommodation unit was registered).

The accommodation capacity by type of units is an indicator that shows the total number of beds by type of tourist reception. Thus, for the Câmpulung Muscel Depression, by analysing two reference years, 2001 and 2008, we notice that there are some differences at the between different settlements. As noted in previous analyses, the communes Albeștii de Muscel şi Valea Mare Pravăț have no accommodation units recorded. For the other administrative units, the city Câmpulung and the communes Bughea de Jos and Lerești some differences are easily observed. An analysis of the accommodation facilities classified by type and number of places (see Figure 3.) shows that, in the city Campulung, in both reference years, the beds available in hotels outnumber the beds offered in other types of accommodation units, although the actual number of beds available in hotels decreases from over 200 places in 2001 to 191 beds in 2008 .

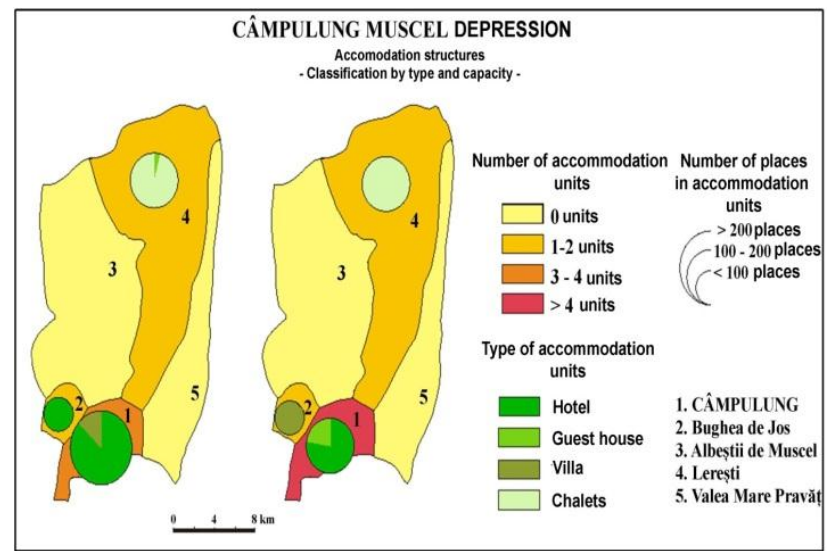

Figure 3. Accommodation units - classification by type and capacity
Regarding the percentage of beds available in different types of accommodation units, it appears that, in 2001 the total number of beds in hotels represent $86.8 \%$ of the total beds available while the remaining $13.2 \%$ are distributed in villas, in turn, in 2008, although the hotels still hold the majority of beds available, their percentage decreased to $77,4 \%$, and the villas have disappeared, making room for boarding houses with a percentage of $22,6 \%$. Regarding the commune of Bughea de Jos the number of beds remains constant between the years analysed, under 100 beds, which are owned entirely by a single type of accommodation, a hotel which was closed in 2008 and was replaced by villas. By analysing figure 6 we notice that in the case of the Lerești commune there aren't major differences regarding the number of beds (between 100 and 200 beds in 2001 and also in 2008). There are only differences when discussing the types of accommodation structures. If in 2001 chalets held the majority with $95.4 \%$ of the total beds available, completed by a small percentage of beds in boarding houses $4.2 \%$ pensions, in 2008 all the beds are available in chalets. The boarding houses were either closed, either transformed into chalets.

\section{Determining the tourism function of the area}

Tourism in a particular region involves a development of general and specific infrastructure in order to ensure optimum conditions for a capitalization of the local tourism resources but in the same time tourism, through its infrastructure puts less or more pressure on the environment. Thus, if we consider only the number of places in accommodation units can we can estimate the intensity of tourism for an area / region / settlement, either by reporting it to the total population of the unit considered, either by reporting it to its dimensions.

By reporting the number of beds available to the permanent population (usually per 1000 inhabitants) of the area / settlement we can calculate one of the most important indicators, which determines if a space can be considered a space for tourism. According to official data, the average tourism function for the study area is 7.2 beds per 1000 inhabitants, but higher values are recorded in different zones. Because there are not accommodation units registered in the communes Albeștii de Muscel and Valea Mare Pravăț, the tourism function is o. According to Figure 4 the communes of Bughea de Jos and Lerești have the highest values of the tourism function, over $15 \%$, because of the great number of beds (as seen in 


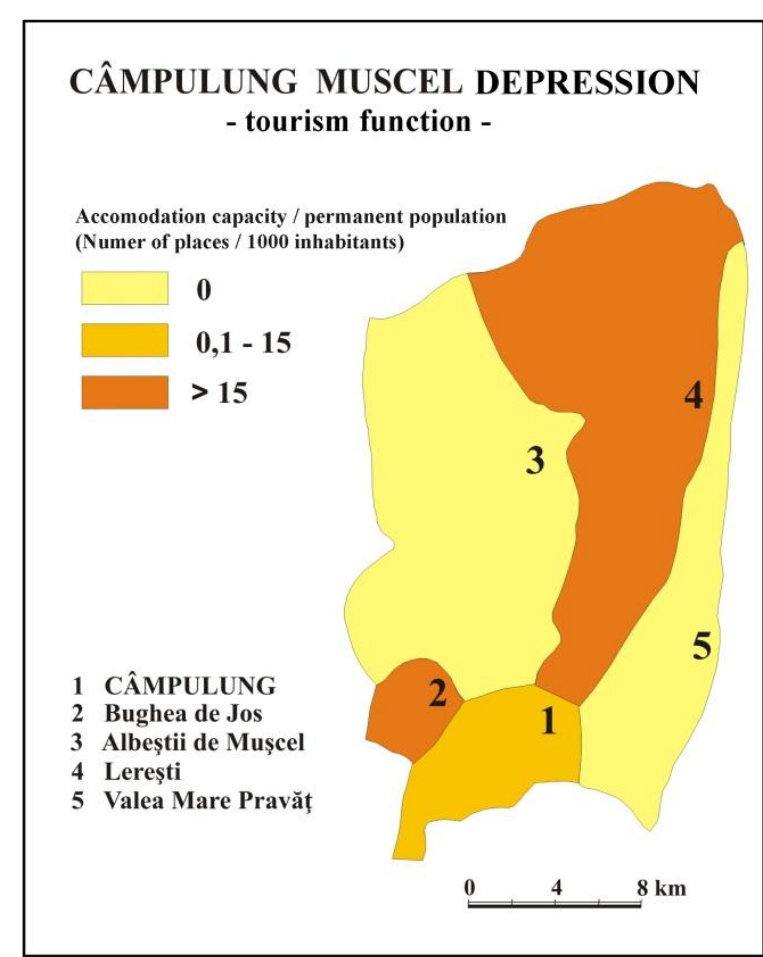

Figure 4. Tourism function

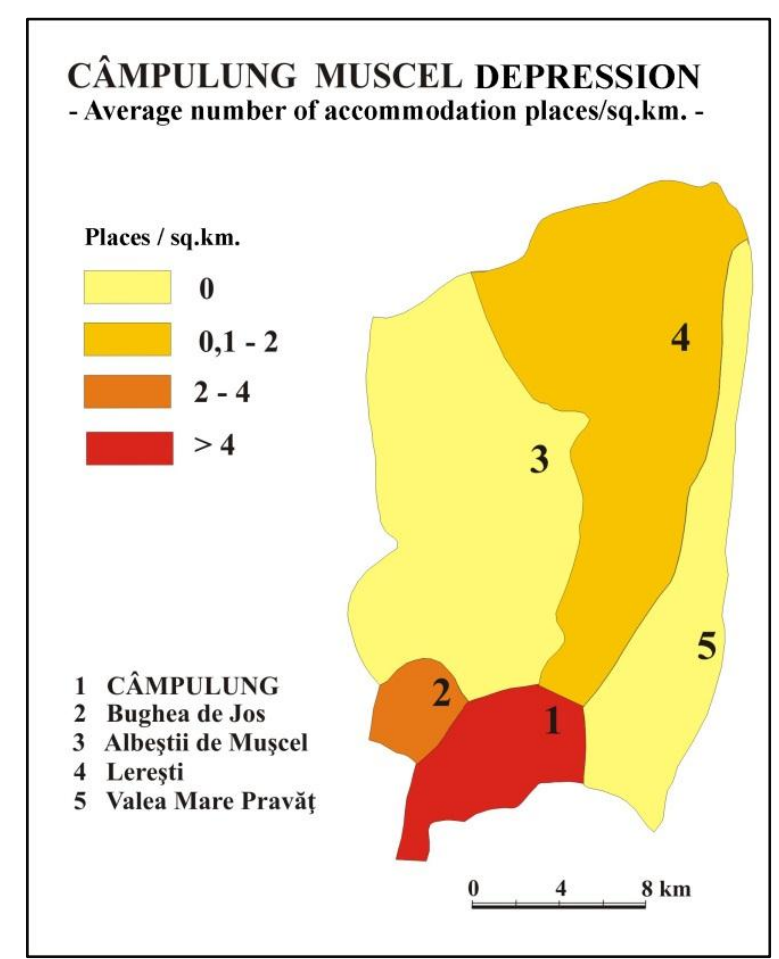

Figure 5. Average number of accommodation places/sq.km.

\section{Conclusions}

function has a value of $5.14 \%$, slightly below the average of the entire region. This is mainly due to the large number of inhabitants, when compared to the other two administrative units mentioned above, Bughea de Jos and Lerești as this reduces the value of the tourism function.

Another indicator that shows the dimensions of tourism in a specific territory is the average number of beds per sq. $\mathrm{km}$. Calculated according to official statistical data, this indicator has the highest value in the city Câmpulung with over 4 places / sq.km, due to the cities small area and its high number of beds available in different accommodation structures. However, for the commune Lereşti, its large area makes this indicator much lower than in Câmpulung, at only 0.95 places / sq.km, even if the number of beds fells within the same range (between 100-200 beds). For the commune Bughea de Jos the value of this index, 2.73 places / km, is due on one hand to the number of beds available, less than 100, fewer when compared with other administrative units, and on the other hand to its small area which is more favorable when calculating this index. For the other two villages, Albeștii de Muscel and Valea Mare Pravăț, no official data regarding the number of units of accommodation and hence the number of beds available, makes it impossible to calculate this indicator, so that, if we consider that in these two villages there aren't any accommodations, then the indicator expressed above is zero
With a massive restructuring of all economic sectors, the development of tourism activities is a priority for most settlements in the Câmpulung Muscel Depression. Given the fact that tourism function is outlined below the optimum possibilities, the economic and legislative priority should be to support the investment in accommodation. In rural areas, organizing the household into accommodation facilities destined strictly for tourist activity would significantly increase the opportunities to exploit the tourism potential, and the accommodation area could be organized in several ways, including: furnished rooms assigned strictly to tourists, of the different categories, in private homes or in specially designed buildings; holiday homes or villas raised by local people, which can be permanent or dependent on tourism demand; transforming locals' courtyards into camping areas (for tents or caravans). However, another key point for tourism planning is linked to the development of access roads and utility infrastructure, rehabilitation of the existing ones and planning new ones in order to increase the accessibility and the living conditions in rural settlements from Câmpulung Muscel Depression.

Under these conditions, working in the housing field could help revitalize economic life of settlements because it creates the possibility for longterm development policies, in close connection with the development of traditional and environmental 
protection. At the same time, activities of tourism accommodation could provide opportunities for new business and jobs and also increase the income of residents from rural settlements through the best use of local resources. Tourism can lead in future to an optimal promotion of local communities in order to support their economic development and raise the living standards of residents. Thus, the strategic objectives to revive tourism in the area should proceed towards a comprehensive partnership and link all initiatives on the present and future of tourism, with the effective participation of public authorities, civil society and private sector to attract resources and local investors, public and private, to diversify and increase tourism services and finally, to increase the number of tourists as well as the direct and indirect income from tourism.

\section{References}

Berbecaru, I \& Botez, M 1977, Teoria și practica amenajării turistice, Editura Sport-Turism, București.
Cooper, C, Fletcker, I, Gilbert, D \& Wanhill, S 1993, Tourism principles and practice, Pitman, London.

Cristureanu, C, Zadig, R \& Baron, P 1982, Economia turismului, Editura A.S.E., Bucureşti.

Erdeli, G \& Gheorghilaş, A 2006, Amenajări turistice, Editura Universitară, Bucureşti.

Firoiu, D 2002, Economia turismului şi amenajarea turistică a teritoriului, Editura Sylvi, București.

Gheorghilaş, A 2006, Bazinul hidrografic Râul Târgului. Potențialul de dezvoltare al aşezărilor umane, Editura Etnologică, Bucureşti.

Gheorghilaș, A 2008, Geografia turismului. Metode de analiză în turism, Editura Universitară, București.

Minciu, R 1995, Amenajarea turistică a teritoriului, Editura Sylvi, București.

Neacşu, N 2000, Turismul şi dezvoltarea durabilă, Editura Expert, Bucureşti.

Prikvil, F 1967, 'Méthode de travail du plan d'aménagement du territoire d'un région de tourisme', Revue de tourisme, nr. 2/1967.

Snak, O, Baron, P \& Neacşu N 2001, Economia turismului, Editura Expert, Bucureşti. 